\title{
Analisis Faktor-faktor yang Mempengaruhi Nilai Tukar Petani Kopi di Provinsi
} Aceh

(Analysis of Factors that Affecting Exchange Rate of Coffee Farmers in Aceh Province)

\author{
Chairuddin $^{1}$, Zulkarnain $^{1}$, Safrida $^{1 *}$ \\ ${ }^{1}$ Prodi Agribisnis, Fakultas Pertanian, Universitas Syiah Kuala \\ *Corresponding author: safrida@unsiah.ac.id
}

\begin{abstract}
Abstrak. Perkebunan merupakan salah satu subsektor yang berpotensi baik dan dapat berkontribusi sebesar $32,43 \%$ dari total PDRB sektor pertanian. Salah satu komoditi perkebunan rakyat yang berpotensi besar adalah kopi yang memiliki pertumbuhan Faisal Andryan produktivitas sebesar $61,25 \%$ dan mampu menyerap tenaga kerja sejumlah 167.196 orang/ha/tahun. Di sisi lain, prospek yang begitu baik dari tanaman kopi ini belum dapat memberi kesejahteraan yang baik terhadap petani kopi. Hal ini terlihat dari penurunan Nilai Tukar Petani Perkebunan rakyat setiap tahunnya. Adapun tujuan penelitian ini untuk menganalisis faktor-faktor yang mempengaruhi nilai tukar petani kopi di Provinsi Aceh. Penelitian ini menggunakan data sekunder dari tahun 2010-2019. Peneliti menggunakan analisis deskriptif dan kuantitatif denga menggunakan metode analisis regresi linier berganda. Hasil penelitian ini menujukkan bahwa variabel PDRB sektor pertanian dan produktivitas kopi berpengaruh signifikan sementara inflasi tingkat pedesaan dan harga kopi di tingkat petani tidak berpengaruh signifikan terhadap nilai tukar petani kopi. Poduktivitas dan harga kopi di tingkat petani memiliki hubungan positif terhadap nilai tukar petani kopi sementara PDRB sektor pertanian dan inflasi di tingkat pedesaan memiliki hubungan negative terhadap nilai tukar petani kopi.
\end{abstract}

Kata Kunci : Nilai Tukar Petani, kopi, kesejahteraan, regresi.

\begin{abstract}
Estate Crops is one of the sub-sectors with good potential and can contribute $32.43 \%$ of the total GRDP of the agricultural sector. One of the commodities that has great potential is coffee which has a productivity growth of $61.25 \%$ and is able to absorb a workforce of 167,196 people/ha/year. On the other hand, the good prospects of this coffee plant have not been able to provide good welfare for coffee farmers. This can be seen from the decreasings of the farmers exchange rate of smallholder plantation farmers in every year. The purpose of this study is to analyze the factors that affect the exchange rate of coffee farmers in Aceh Province. This study uses secondary data from 2010-2019. The researcher used descriptive and quantitative analysis using multiple linear regression analysis method. The results of this study indicate that the agricultural sector GRDP and coffee productivity variables have a significant effect, while rural inflation and coffee prices at the farm level have no significant effect on the coffee farmers' exchange rate. Productivity and coffee prices at the farm level have a positive relationship to the exchange rate of coffee farmers while the GRDP of the agricultural sector and inflation at the rural level have a negative relationship to the exchange rate of coffee farmers.
\end{abstract}

Keywords : Farmers Exchange Rate, Coffee, walfare, regression.

\section{PENDAHULUAN}

Subsektor perkebunan merupakan salah satu subsektor yang memiliki potensi besar pada sektor pertanian Provinsi Aceh. Letak geografis serta iklim mendukung berbagai jenis komoditi perkebunan tumbuh dengan baik dan memiliki daya saing di pasar dalam negeri maupun luar negeri. subsektor perkebunan memberi kontribusi yang tinggi pula pada PDRB sektor pertanian Provinsi Aceh. Dalam kurun tahun 2014-2019 subsektor perkebunan memberi kontribusi yang sangat baik hingga 33,836\% dari total PDRB sektor pertanian.

Berdasarkan status pengusahaannya, subsektor tanaman perkebunan di Indonesia dibagi menjadi perkebunan rakyat (PR), perkebunan besar negara $(\mathrm{PBN})$ dan perkebunan besar swasta (PBS). Perkebunan rakyat menjadi sumber mata pencaharian bagi sebagian besar mesyarakat 
Aceh. Besarnya luas areal perkebunan rakyat juga lebih besar dibandingkan perkebunan lainnya (Pertiwi, 2018).

Salah satu komoditi yang memiliki prospek sangat baik pada subsektor perkebunan khususnya perkebunan rakyat adalah kopi. Provinsi Aceh dikenal mampu memproduksi kopi dengan kualitas yang baik dan mampu bersaing di pasar internasional. Nilai tambah serta permintaan komoditi kopi juga lebih tinggi apabila dibandingkan dengan komoditi perkebunan lainnya. . Komoditi kopi mampu menyerap tenaga kerja sejumlah 167.196 orang/ha/tahun dan mampu berproduktivitas sebesar $593 \mathrm{~kg} / \mathrm{ha}$. Peningkatan produktivitas kopi dalam enam tahun terakhir meningkat dengan sangat signifikan. Hal ini ditunjukkan dengan angka pertumbuhan yang mencapai $61 \%$. Hal ini juga mengindikasikan bahwa permintaan kopi di pasar lokal ataupun internasional mengalami peningkatan yang cukup tinggi.

Namun di sisi lain, angka pertumbuhan dan penyerapan tenaga kerja dari komoditi kopi belum mampu memberi dampak secara merata yang berdampak tidak maksimalnya hasil yang diterima pada petani kopi. Nilai tukar petani (NTP) subsektor tanaman perkebunan sebagai salah satu indikator tingkat kesejahteraan petani kopi menunjukkan indeks yang masih rendah bahkan menjadi yang terendah dan terus mengalami penurunan dibandingkan dengan subsektor pertanian lainnya. Bahkan nilai tukar petani dalam kurun 5 tahun terakhir tidak pernah berada di atas angka 100. Kondisi ini menunjukkan sistem agribisnis yang terbangun belum sepenuhnya mensejahterakan petani. Berbagai faktor baik internal maupun eksternal dapat mempengaruhi yang mempengaruhi nilai tukar petani. Oleh sebab itu, berdasarkan latar belakang di atas perlu dilakukan suatu analisis terkait faktor-faktor yang mempengaruhi nilai tukar petani kopi untuk mengetahui faktor-faktor yang paling berpengaruh terhadap nilai tukar petani kopi. Tujuan penelitian Adapun tujuan penelitian ini, yaitu untuk mengidentifikasi faktor-faktor yang berpengaruh terhadap nilai tukar petani kopi Provinsi Aceh.

\section{METODE PENELITIAN}

\section{Tempat dan Waktu Penelitian}

Penelitian ini dilakukan di Provinsi Aceh dengan menggunakan data sekunder dalam bentuk deret waktu dengan rentang waktu tahun 2010-2019 yang didapat dari Badan Pusat Statistik. Waktu penelitian ini dilakukan pada bulan Maret-Juni 2021.

\section{Objek dan Ruang Lingkup Penelitian}

Ruang lingkup penelitian ini terbatas pada faktor produktivitas, harga produsen, indeks harga konsumen, PDRB dan inflasi tingkat pedesaan yang mempengaruhi nilai tukar petani kopi di Provinsi Aceh. Adapun objek yang digunakan dalam penelitian ini adalah nilai tukar petani subsektor perkebunan rakyat.

\section{Jenis dan Sumber Data}

Jenis data yang digunakan dalam penelitian ini merupakan data sekunder. Jenis data beserta sumbernya berasal dari Badan Pusat Statistik (BPS) dan instansi-instansi terkait. Data yang digunakan berupa data deret waktu (time series) periode tahunan, dengan periode tahun 2010 hingga periode tahun 2019.

\section{Metode Analisis}

Metode analisis yang digunakan dalam penelitian ini adalah secara deskriptif dan kuantitatif dengan metode metode Analisis Regresi Linear Berganda yang dapat 
mengidentifikasi faktor-faktor yang mempengaruhi nilai tukar petani kopi. Adapun model persamaan yang digunakan pada penelitian ini sebagai berikut:

Keterangan :

$$
\mathrm{NTPR}=\beta 0+\beta 1 \mathrm{~V}+\beta 2 \mathrm{P}+\beta 3 \mathrm{GRDPAG}+\beta 4 \mathrm{Inf}+\mathrm{e}
$$

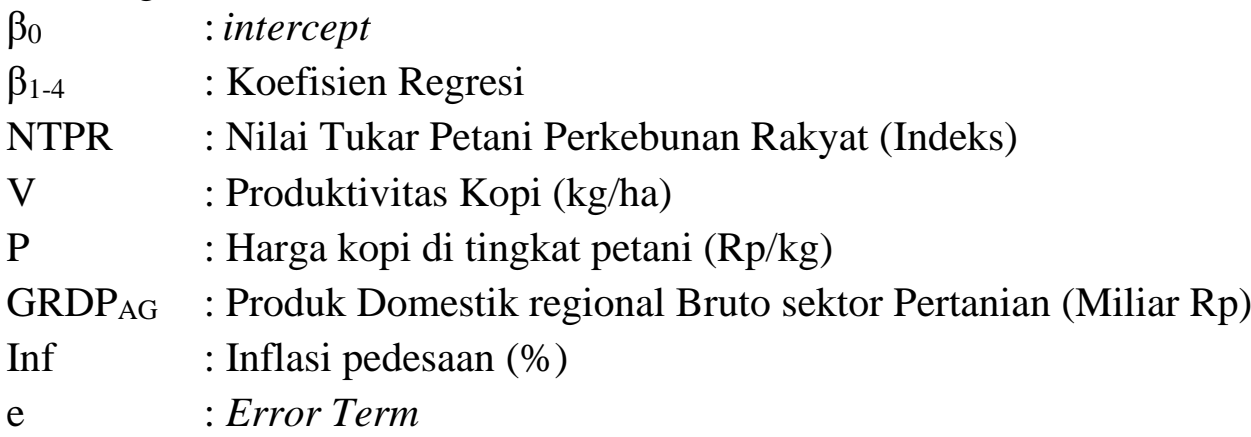

Dalam penelitian ini metode pendugaan model yang digunakan adalah analisis regresi berganda. Pengujian hipotesis dilakukan untuk mengetahui pengaruh variabel dengan menggunakan pengujian sebagai berikut :

a) Uji F (serempak)

Uji ini dilakukan untuk mengetahui apakah semua variabel yang dimasukkan dalam model mempunyai pengaruh secara bersama. Untuk melihat pengaruh secara serempak dapat dilihat dengan menggunakan rumus sebagai berikut:

Dimana:

$$
\text { F hitung }=\frac{R^{2} / K}{\left(\frac{1-R^{2}}{n-K-1}\right)}
$$

R2 : Koefisien Determinan

K : Variabel Peubah Bebas

n : Jumlah Sampel

Dengan kriteria :

1. Apabila $\mathrm{F}$ (hitung) $>\mathrm{F}($ tabel) , maka Ha diterima dan $\mathrm{H} 0$ ditolak, yaitu variabel bebas mempunyai pengaruh yang signifikan terhadap variabel terikat.

2. Apabila $\mathrm{F}$ (hitung) < $\mathrm{F}($ tabel $)$, maka Ha ditolak dan $\mathrm{H} 0$ diterima, yaitu variabel bebas tidak mempunyai pengaruh signifikan terhadap variabel terikat.

b) Uji T (Parsial)

Uji beda t-test digunakan untuk mengetahui seberapa jauh pengaruh variabel yang digunakan dalam penelitian ini secara individu dalam menjelaskan variabel lain secara parsial. Untuk pengujian secara parsial, dapat dilihat dengan rumus sebagai berikut:

Dimana :

$$
\text { thitung }=\frac{b i}{S b i}
$$

bi : Koefisien Regresi

Sbi : Standard error dari koefisien regresi

Dengan kriteria :

1. Apabila thitung > ttabel, maka Ha diterima dan $\mathrm{H}_{0}$ ditolak, yang berarti variabel bebas berpengaruh signifikan terhadap variabel terikat. 
2. Apabila thitung < ttabel, maka Ha ditolak dan $\mathrm{H}_{0}$ diterima, yang berarti variabel bebas tidak berpengaruh signifikan terhadap variabel terikat.

c) Koefisien Determinasi $\left(\mathrm{R}^{2}\right)$

Koefisien determinasi $\left(\mathrm{R}^{2}\right)$ untuk mengetahui seberapa besar kemampuan model dalam menerangkan variasi variabel. Untuk mengetahui bagaimana hubungan antara variabel bebas dan variabel terikat, maka digunakan koefisien determinasi $\left(\mathrm{R}^{2}\right)$ dengan rumus :

Dimana :

$$
R^{2}=\frac{J K(\operatorname{Reg})}{\Sigma y i^{2}}
$$

$$
\begin{aligned}
& \mathrm{R}^{2} \text { : Koefisien Determinasi } \\
& \text { JKreg: Jumlah Kuadrat untuk Regresi } \\
& \mathrm{Yi}^{2} \text { : Jumlah Kuadrat Lokal }
\end{aligned}
$$

\section{HASIL DAN PEMBAHASAN}

\section{Analisis Faktor-Faktor yang Mempengaruhi Nilai Tukar Petani Kopi di Provinsi Aceh}

Hasil penelitian ini menunjukkan nilai koefisien determinasi (R-Square) sebesar 0,977 yang artinya variabel dalam model persamaan dapat menjelaskan Nilai Tukar Petani Kopi sebesar 97,7\% sementara sisanya dijelaskan oleh variabel di luar model. Hasil pengujian secara serempak pada tingkat keyakinan $90 \%(\alpha=0,1)$ diperoleh nilai $\mathrm{F}_{\text {hitung }}=34,32$ dan $\mathrm{F}_{\text {tabel }}=2,69$ sehingga $\mathrm{F}$ (hitung) $>\mathrm{F}$ (tabel), yang artinya secara serempak variabel pada persamaan berpengaruh berpengaruh nyata terhadap variabel PDRB sektor pertanian di Provinsi Aceh.

Nilai konstanta pada persamaan PDRB sektor pertanian adalah sebesar 155,85 yang berarti apabila semua variabel bebas yang ada pada persamaan NTP kopi di tahun tertentu dianggap konstan maka NTP kopi di Provinsi Aceh meningkat sebesar 155,85 per tahun.

Tabel 1. Hasil Estimasi Faktor yang Mempengaruhi NTP Kopi di Provinsi Aceh

\begin{tabular}{lcccc}
\hline Equation & & sq" & "R- & F-Stat \\
\hline Nilai Tukar Petani Kopi & & & $\mathbf{0 , 9 7 7}$ & $\mathbf{3 4 , 3 2 9}$ \\
\hline & Coef. & Ratio & T- & Sig. \\
\hline Konstanta & 155,85 & 7,692 & 0,001 \\
PDRB $_{\text {AG }}$ & $-0,002$ & - & 0,002
\end{tabular}




$\begin{array}{lccc}\text { Inflasi } & -0,024 & -1,76 & 0,868 \\ \text { Produktivitas Kopi } & 0,72 & 4,003 & 0,016 \\ \text { Harga Kopi di tingkat Petani } & 2,018 \mathrm{E}- & 1,102 & 0,332\end{array}$

Sumber : data diolah (2021)

Berdasarakan Tabel 1, persamaan nilai tukar petani kopi dapat dibuat dalam bentuk matematis sebagai berikut:

$$
\mathrm{NTP}=155,85-0,002 \mathrm{PDRB} \mathrm{AG}_{\mathrm{A}}-0,024 \mathrm{Inf}+0,72 \mathrm{~V}+2,018 \mathrm{e}^{-6} \mathrm{Pp}
$$

Produk domestik regional bruto sektor pertanian memiliki nilai koefisien estimasi sebesar 0,002 yang bermakna setiap kali PDRB sektor pertanian meningkat sebesar 1 miliar, maka akan menurunkan NTP sebesar 0,002. Hubungan PDRB sektor pertanian dan NTP kopi adalah negatif. Berdasarkan hasil analisis statistik uji t, nilai sig. $<\alpha$ hal ini menunjukkan bahwa PDRB sektor pertanian berpengaruh nyata terhadap NTP kopi. hasil penelitian oleh Simatupang dan Isdisojo (1992) yang menyimpulkan nilai tukar petani cenderung menurun seiring dengan peningkatan laju pertumbuhan ekonomi, karena permintaan terhadap produk pertanian tidak elastis. Istiana (2018) menambahkan bahwa nilai PDRB yang tinggi belum tentu menjamin kesejahteraan petani yang tinggi. Hal ini dapat terjadi karena adanya hubungan PDRB dengan kontribusi usahatani terhadap pendapatan.

Inflasi pedesaan memiliki nilai koefisien estimasi sebesar -0,024 yang bermakna setiap kali inflasi pedesaan naik sebesar satu persen, maka akan menurunkan NTP kopi sebesar 0,024. Hubungan nilai ekspor sektor pertanian dan NTP kopi adalah negatif hal ini sesuai dengan teori dan nilai persamaan yang diharapkan pada persamaan ini. Berdasarkan hasil analisis statistik uji t, nilai Sig. $>\alpha$ yang artinya inflasi pedesaan tidak berpengaruh nyata terhadap NTP kopi. Hal ini disebabkan karena perubahan nilai inflasi pedesaan pada tahun pengamatan masih dalam keadaan yang rendah atau wajar sehingga tidak mempengaruhi NTP kopi secara nyata.

Produktivitas kopi memiliki nilai koefisien estimasi sebesar 0,72 yang bermakna setiap kali produktivitas kopi naik sebesar $1 \mathrm{~kg} / \mathrm{ha}$, maka akan meningkatkan NTP kopi sebesar 0,72. Hubungan nilai ekspor sektor pertanian dan NTP kopi adalah positif. Berdasarkan hasil analisis statistik uji t, nilai sig. $<\alpha$ yang artinya produktivitas kopi berpengaruh nyata terhadap NTP kopi. Hasil penelitian ini didukung dengan kesimpulan dari penelitian yang telah dilakukan oleh Febriana (2015) yang menunjukkan bahwa produksi berpengaruh positif dan signifikan terhadap nilai tukar petani dikarenakan produksi bergantung kepada luas lahan dan produktivitas per hektar, sehingga apabila salah satu dari kedua variabel tersebut meningkat maka akan meningkatkan kesejahteraan petani.

Harga kopi memiliki nilai koefisien estimasi sebesar 2,018 $\mathrm{e}^{-6}$ yang bermakna setiap kali Harga kopi naik $100.000 \mathrm{Rp} / \mathrm{kg}$ maka akan meningkatkan nilai tukar petani kopi sebanyak 0,2018. Hubungan nilai ekspor sektor pertanian dan Nilai tukar petani kopi adalah positif. Berdasarkan hasil analisis statistik uji t, nilai sig. $>\alpha$ yang artinya Harga kopi tidak berpengaruh nyata terhadap Nilai tukar petani kopi. Novitasari (2017) dalam penelitiannya juga menanmbahkan bahwa kontribusi usahatani kopi terhadap pendapatan keluarga petani kopi masih tergolong sedang yaitu hanya sekitar 33-66\%. Hal ini disebabkan karena petani kopi juga memiliki pekerjaan lainnya seperti kuli bangunan dan lain sebagainya sehingga harga kopi sebagai acuan pendapatan usahatani kopi bukan menjadi satu-satunya sumber pendapatan petani kopi. 


\section{KESIMPULAN DAN SARAN}

\section{Kesimpulan}

Berdasarkan hasil analisis dan pembahasan didapati bahwa variabel yang berpengaruh signifikan terhadap nilai tukar petani (NTP) kopi adalah PDRB sektor pertanian dan produktivitas kopi sementara variabel inflasi pedesaan dan harga kopi di tingkat petani tidak berpengaruh signifikan. Harga dan produktivitas kopi memiliki nilai positif terhadap nilai tukar petani kopi sementara PDRB dan Inflasi memiliki nilai negatif terhadap nilai tukar petani kopi.

\section{Saran}

Untuk meningkatkan kesejahteraan petani kopi secara efektif maka diperlukan suatu kebijakan ataupun usaha untuk meningkatan produktivitas kopi dan diharapkan kepada pemerintah dapat menjamin stabilitas perekonomian dengan memerhatikan pertumbuhan PDRB sektor pertanian.

\section{DAFTAR PUSTAKA}

Istiana, F. A. 2018. Analisis Faktor-Faktor yang Mempengaruhi Nilai Tukar Petani di Indonesia Tahun 2013-2017. Skripsi. Universitas Islam Indonesia, Yogyakarta.

Badan Pusat Statistik. 2020. Provinsi Aceh Dalam Angka. Badan Pusat Statistik Provinsi Aceh, Banda Aceh.

Chairul Muslim. 2017. Nilai Tukar Petani Komoditas Perkebunan. Jurnal SEPA : Vol. 13 No.2 Februari 2017 : 142 - 158 ISSN : 1829-9946

Evendi Akhmad. 2018. Nilai Tukar Petani Provinsi Bali Tahun 2015-2017. Jurnal Manajemen Agribisnis, Vol.6, No.1, Mei 2018 ISSN: 2355-0759.

Fita Febriana. 2015. Analisis Faktor-Faktor Yang Mempengaruhi Nilai Tukar Petani Di Provinsi Jawa Timur. Program Studi Ekonomi Pembangunan Jurusan Ilmu Ekonomi Dan Studi Pembangunan Fakultas Ekonomi Universitas Jember. Jember.

Novitasari, S. 2017. Kontribusi Kontribusi Usahatani Kopi Pada Pendapatan Keluarga Dan Strategi Pengembangannya Di Des Bumi Agung Kecamatan Dempo Utara Kota Pagar Alam. Skripsi. Fakultas Pertanian Universitas Sriwijaya.

Purba, T.Y. 2017. Dampak Nilai Tukar Petani Terhdap Kesejahteraan Petani Cabai Merah (Capsicum Anum L.). (Kasus; Desa Hinalang, Kecamatan Purba, Kabupaten Simalungun.) Skripi. Universitas Sumatera Utara. Medan.

Sari, C.N.P, Jumiati, A dan Muslihatinnigsih, V. 2019. Analisis Pengaruh Inflasi dan Investasi Terhadap Pertumbuhan Ekonomi dan Kesejahteraan Masyarakat di Pulau Jawa Tahun 2006-2016. Jurnal Ekonomi Ekuilibrium. Vol. 3 No. 1.

Soediyono. 1992. Teori Ekonomi Mikro. Pengantar Analisis Pendapatan Nasional. Yogyakarta: Liberty. 
Simanjuntak, M., \& Bhakti, A. (2018). Pengaruh PDRB sektor pertanian, nilai tukar petani dan investasi sektor pertanian terhadap penyerapan tenaga kerja sektor pertanian Provinsi Jambi, 7(1), 1-12.

Simatupang, P. 1992. Pertambahan Ekonomi dan Nilai Tukar Pertanian Sub Sektor Pertanian. Pusat Penelitian Sosial Ekonomi Pertanian, Bogor.

Taufik, M., Purtomo, R. S., Viphindrartin, S. 2016. Pengaruh Pengeluaran Pemerintah Di Sektor Pertanian Terhadap PDRB Sektor Pertanian di wilayah EKS Karesidenan Basuki. Artikel Mahasiswa. Fakultas Ekonomi, Universitas Jember, Jember.

Wibowo, A. A. 2018. Analasis Faktor-faktor yang Mempengaruhi Upah Minimum Regional (UMR) Provinsi Daerah Istimewa Yogyakarta Tahun 1990-2016. Skripsi. Universitas Muhammadiyah Surakarta, Surakarta 